\title{
Logical Design of Legal Education. Towards the Anniversary of Kutafin Moscow State Law University
}

\author{
Olga V. Malyukova \\ Kutafin Moscow State Law University (MSAL), Moscow, Russia
}

\begin{abstract}
The paper deals with the problem of interrelation between two research programs - logic and jurisprudence - from antiquity to the present. Traditional logic has created and developed the Great Triad "Concept - Judgment - Inference" that has become an educational and methodological canon of humanitarian knowledge and education in general and legal knowledge and legal education in particular. The doctrine of the concept, the doctrine of judgment, the doctrine of inference (more precisely, the doctrine of proof) are essentially used in legal proceedings, law-making, and law enforcement. The author resorts to modern achievements of the theory and technology of scientific knowledge as a research methodology. Logical knowledge itself appears in the form of methodology. Under this approach, any science, both natural and humanitarian, necessarily defines its conceptual corpus. Any science, creating its own description of the subject area, uses theoretical provisions in the form of a set of theses and arguments expressed by judgments. Any science substantiates its vision of the world using a system of evidence. All these properties are subject to and correspond to the subject of logics taught in every law school in the context of legal logics or logics for lawyers. The place of logic in the framework of legal education is considered as a hierarchy of problems of the relation between the phenomena of "the logical" and "the legal" within the framework of the world-historical process, the relation between the phenomena of "the logical" and "the legal" within the framework of domestic history and domestic education system before 1917, i.e., before the overthrow of the monarchy and the
\end{abstract}


establishment of the Soviet power, the relation between the phenomena of "the legal" and "the logical" in Soviet and post-Soviet history, creation of an education system, including legal education, in our country and the development of the logical science and logical education at Kutafin Moscow State Law University. The uniqueness of the study is associated with the use of the Transcript of the All-Soviet Meeting of Logic Teachers of Higher Educational Institutions held on June 21-26, 1948 in Moscow discovered and introduced into scientific circulation by the author of the paper. The result of the study proves the special importance of logic for lawyers as a reliable tool in situations of lawmaking, law enforcement and interpretation of legal norms.

Keywords: Formal and dialectical logic; concept; judgment; inference; logical culture of thinking; legal logic; logical education; Sector of Logic

Cite as: Malyukova, O.V., (2021). The Logical Design of Legal Education. Towards the Anniversary of Kutafin Moscow State Law University. Kutafin Law Review, 8(4), pp. 647-667, doi: 10.17803/23135395.2021.4.18.647-667.

\section{Contents}

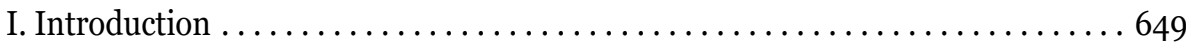

II. Interrelation between the Terms "the Logical" and "the Legal" in the Framework of the World Historical Process .................. 650

III. Interrelation between the Terms "the Logical" and "the Legal" in the Framework of National History and the National Education

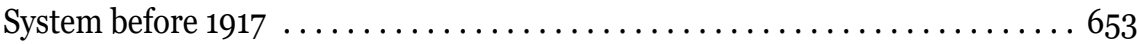

IV. Interrelation between the Terms "the Logical" and "the Legal"

in the Soviet and Post-Soviet History: Establishment of Education System and Legal Education in Russia ............................. 655

V. Logical Science and Logical Education

at Kutafin Moscow State Law University . . . . . . . . . . . . . . . . . . 663

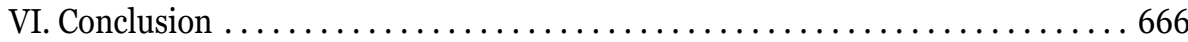

References .............................................. 666 
As for science, everything is simple here: You take the rule of law in one hand (as a general rule), in the other hand you take the client's story (as a special case), and you push one on top of the other. If it doesn't work, add the necessary details or remove unnecessary ones.

This is called "building a syllogism" and refers to formal logic that is taught during the first year of the university.

Vladimir Livshits

\section{Introduction}

Traditional logic has created and developed the Great Triad "Concept - Judgment - Inference" that has become an educational and methodological canon of humanitarian knowledge and education in general, and legal knowledge and education in particular. Strictly speaking, this is exactly what Vladimir Livshits, a famous practicing advocate and the author of the book describing advocate's daily life, tells us about in his story (Livshits, 2009). Indeed, syllogistics remains in Livshit's memory and in the memory of many lawyers, although in fact traditional logical knowledge is the aforementioned triad, and he treats syllogistics rather cautiously and does not consider it a leading component of logic. The doctrine of the concept, the doctrine of judgment, the doctrine of inference (more precisely, the doctrine of proof) developed by logic are essentially used in legal proceedings, law-making and law enforcement. For the first time, a student actually encounters a logical complex of knowledge during the first year at a law school, because secondary schools for inexplicable reasons have been withdrawn from the formation of logical culture. Applicants are sure that a concept is what they have understood, judgment is an opinion or point of view, and inference is an intuitive cognitive act. Logical education aims at eliminating this gap and forming a logical culture of thinking. Any science, both natural and humanitarian, necessarily defines its conceptual corpus. Any science, creating its own description of the subject area, uses theoretical provisions in the form of a set of theses and arguments expressed by judgments. Any science substantiates its 
vision of the world using a system of evidence. All these properties are present in jurisprudence.

A logical design or logical support of legal education at Kutafin Moscow State Law University is an undoubted fact and a circumstance that significantly influenced the nature and content of legal education because, being the common basis of humanitarian education, logic (and rhetoric).constitutes a unifying factor for it in general, That is why logic as a science and logic as an academic discipline has always occupied a worthy place within the educational program of Kutafin Moscow State Law Academy (former All-Union Correspondence Law Institute).

A decent place of logic in the framework of legal education is associated with a number of circumstances and can be considered as a certain hierarchy of the relevant problem:

The first element of the hierarchy involves the correlation between the phenomena (terms) of "the logical" and "the legal" within the framework of the world-historical process.

The second element involves the correlation between the phenomena of "the logical" and "the legal" within the framework of national history and the national education system before 1917, i.e., until the overthrow of the monarchy and the establishment of Soviet power.

The third element concerns the interrelation between precisely "the logical" and "the legal" in Soviet and post-Soviet history, as well as the creation of an education system, including legal education in our country.

The forth element involves the logical science and logical education at Moscow State Law University.

\section{Interrelation between the Terms "the Logical" and "the Legal" in the Framework of the World Historical Process}

The appearance of the terms "the logical" and "the legal" in their traditional form should be attributed to the era of classical antiquity that begins in the 8th century BC. The Logical (or initially the rhetorical) is realized in the educational sphere, namely, in the activities of rhetorical schools. The legal is embodied in practice, namely, in the system 
of court proceedings. Both phenomena represent a combined interest in the argumentative practices, systems of arguments, i.e., in reasoning.

Until now, logic has been defined as the theoretical science of correct reasoning. The internal sources of the logic emergence include formulas, reasoning and proofs. These basic phenomena are necessarily present in the science of logic, but they arose long before its appearance. In the historical order, formulas first appeared about 4 thousand years ago in the Ancient East. Then, in the 7th century BC in ancient Greece, the first reasoning was recorded, and then in the 6th century $\mathrm{BC}$ the first proofs appeared (see Thales' theorem and Pythagoras' theorem).

The external factors of the emergence of logic include problems with reasoning that arose in connection with the appearance of sophisms and the discovery of paradoxes. Sophistry appears in Greece in the 1st half of the $5^{\text {th }}$ century BC, i.e., about a century before logic appeared. The first examples of paradoxes appeared even earlier. Sophisms and paradoxes turned out to be linguistic reasoning, unacceptable for unknown reasons. Logic was called upon to overcome the problems that arose in reasoning (Anisov, 2002).

The emergence of sophistry is directly related to the development of legal practices, in particular, the judicial system. In the second half

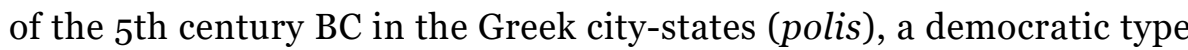
of government was established where the aristocracy lost its political privileges, but retained its wealth. In the new conditions, courts were gaining in importance: every free citizen could summon another citizen to court in order to compensate for actual or perceived damage. It is not a matter of the poor, so the danger of being summoned to court as a defendant threatened primarily the wealthy strata of the population. Unlike the modern court, where the prosecution and the protection is the business of legal professionals (prosecutors and lawyers), in the wood of ancient-Greek court a plaintiff and a defendant had to accuse and defend themselves, speaking for themselves personally.

A large number of judges decided the cases publicly, and even with a large gathering of people, judge's opinion often played a decisive role, and, therefore, the plaintiff and the defendant had to convince the audience that they were right. It was impossible to do without reasoning but, after all, not everyone possessed this art to the proper extent. Now 
there are paid teachers of eloquence - sophists ready to teach the art of persuasion to anyone who has the opportunity to pay them. The goal of this art is to win an argument.

For already in antiquity, in a legal dispute, the main thing was to win the case, even if in reality you were wrong. The Sophists tried to give the same status to different and opposite human interests, their complete cognitive equal right. The famous sophist Protagoras, for example, stated: "Of all things the measure is man, of the things that are, that they are, and of the things that are not, that they are not." Sophistry, as an extreme expression of relativism was very comfortable Philosophy, because it allows justifying everything, anything. Since a man is the measure of all things, then he acts as a measure of truth and falsehood. Hence the thesis of the sophists that every statement can be justified or disproved with equal success. As an example of this thesis, numerous sophisms were created, clever tricks that implicitly contained a logical error.

Generally speaking, a logically erroneous course in reasoning is called paralogism, and sophism is a deliberately veiled paralogism calculated on ignorance of logic and theory of reasoning. In those days when logic did not exist, judicial practice could not oppose anything to sophistry; therefore, the task of creating a logical science was extremely relevant. Furthermore, in the process of reasoning philosophers, lawyers, speakers and others, accidentally and unintentionally, got into an argumentative dead end, the way out of which was not obvious. For example, from an intuitive point of view, the reasoning did not contain paralogisms, but suddenly it led to unacceptable conclusions. A convincing reasoning that leads to an unacceptable conclusion is called a paradox. The most famous reasoning of this type is the liar paradox.

The action of internal and external factors ultimately had a beneficial effect. The science called traditional logic or syllogistic was created by Aristotle in the 4th century BC and existed unchanged for over two thousand years. This is an unprecedented event in the history of science. All other sciences changed, and only logic remained aloof from the large and small scientific revolutions that were taking place. No significant transformations in logic occurred in antiquity, in the 
Middle Ages, or in modern times. Philosophers, logicians, lawyers, physicians and theologians of subsequent centuries only expounded and commented on the works of Aristotle. Indeed, minor changes took place, for example, the philosophical understanding of logic changed, the sets of terms changed, new logical examples appeared, individual additions and clarifications were created, but the core of logic remained unshakable. This core consisted of three parts: the doctrine of the concept, the doctrine of judgment, and the doctrine of inference. In the educational literature, the scheme of presentation of the material was lined up in the form of a chain of concept-judgment - inference. This scheme seemed very reasonable for twenty-five centuries.

In this configuration, at the end of antiquity in the 8th century $\mathrm{AD}$, logic became a part of the "seven liberal arts," which, in addition to logic, included grammar, rhetoric, arithmetic, geometry, music and astronomy. In medieval Western Europe, an educated person could be considered only one who studied this cycle of disciplines in a general education school or, in a deeper version, in the emerging universities at the "faculties of arts" (otherwise the propaedeutic or philosophy faculty). The Faculty of Arts was the first stage of higher education, and the second stage was represented by the Faculties of Theology, Medicine and Law. This structure of universities remained until the 18th century. Thus, Moscow University was still created according to this principle (of course, without a theological faculty, which is impossible for Orthodoxy). Thus, logic entered the required set of disciplines in the legal educational program. It is because of this circumstance that the factual material of logic (examples and explanations) made significant use of the data of legal science and practice.

\section{Interrelation between the Terms "the Logical" and "the Legal" in the Framework of National History and the National Education System before 1917}

The history of logic in Russia begins in the 17th-18th centuries and represents an acquaintance with logic as an academic discipline. Logic was taught at the first higher theological educational institution in Moscow, the Slavic-Greek-Latin Academy, built on the model of the 
Kiev-Mohyla Academy. It taught in accordance with the canon of the "seven liberal arts," and Hieromonk Sophronius Likhud (1652-1730) became the first teacher of logic and the head of the Academy (Slinin and Fedeorov, 2001). And he did teach the logic.

According to the information available, Hieromonk Sophronius Likhud began reading logic on March 17, 1690, and quitted his career on August 11, 1694. But he did not have a chance to read philosophy. Likewise, in 1694, the Likhud brothers (elder brother Ioanniki) were dismissed from the Academy with the wording "We were having fun around philosophy." Theological education did not require the knowledge of philosophy, and there was no other education in Russia available at that time. However, after a while the Likhud brothers resumed teaching at the academy. Moreover, they are considered to be the founders of Russian higher education.

The epoch of Peter the Great transformations, the formation of the secular system of Russian education made logic a standard discipline taught initially in Latin and Greek, and then in Russian. The 19th century became quite favorable for logic as an official academic discipline. Logic was taught in higher educational institutions, in gymnasiums and real schools, as well as in all theological educational institutions. In the Russian Empire, legal educational institutions appeared in addition to the law faculties of universities. Tsarskoye Selo Lyceum (1811-1918), the School of Law (1835-1918), etc. had a legal profile. One of the first professors of Tsarskoye Selo Lyceum Prof. Nikolai F. Koshansky (1781-1831) wrote quite successful textbooks "General Rhetoric" and "Private Rhetoric," using which several generations of students studied. Logic at the Lyceum was also taught by Aleksandr P. Kunitsyn, who was praised by his students Aleksandr S. Pushkin, Aleksandr I. Galich and many others. The majority of the faculty had a law degree and were well acquainted with logic. A number of disciplines of the logical cycle were developed, namely, logic, rhetoric, exegesis, Russian literature. Gradually, logic has become not only an academic subject, but also a field of scientific research. The first Russian scholars appeared in the field of logic, both traditional and symbolic. Indeed, figures of the level of de Morgan, Frege, and Boole did not appear in Russia, but Russian logicians founded their own schools of thought dealing with the subject 
matter of logic; they offered new solutions to important logical problems. Aleksandr I. Vvedensky, Mikhail I. Vladislavlev, Nikolai Ya. Groth, Mikhail I. Karinsky, Leonid V. Rutkovsky, Platon S. Poretsky and others formed the core of the school of logic in Russia. At the beginning of the 2oth century, logic continues to develop both as an academic discipline in universities and gymnasiums, and as a direction of scientific research. Specialists in logic were trained, textbooks and teaching aids for selfeducation were published. The most famous authors of textbooks on logic were Mikhail I. Vladislavlev and Aleksandr I. Vvedensky, Vladimir M. Karinsky, Aleksandr E. Svetilin, Georgiy I. Chelpanov, Sergei I. Povarnin and others. Textbooks by Willam Minto, Christoph von Sigwart et al. were translated into Russian.

\section{Interrelation between the Terms "the Logical" and "the Legal" in the Soviet and Post-Soviet History: Establishment of Education System and Legal Education in Russia}

A natural progressive development of logic ceased after the Great October Socialist Revolution (1917). This did not happen immediately, but gradually. There were practically no representatives of the Bolshevik Party among the teachers, the university faculties and scholars in the humanities. Among university professors in philosophy, jurisprudence, logic predominated the representatives of the cadets political party ${ }^{1}$ and Socialist-Revolutionaries. ${ }^{2}$ Many of them (Nikolai A. Berdyaev, Pyotr B. Struve, et al.) went through the stage of "legal Marxism."3 They knew the philosophy of Marxism well and saw its shortcomings. And most importantly, none of the pre-revolutionary teachers of the humanities envisioned the actual introduction of a monopoly on beliefs: they

${ }^{1}$ Cadets Party (or Constitutional Democracy Party) was a centrist, liberal political party in the Russian Empire promoting Western constitutional monarchy.

${ }^{2}$ Socialist Revolutionary Party (or Party of Socialist-Revolutionaries) was a leading political party in the late Imperial Russia and early Soviet Russia promoting socialist ideas and democracy supporters.

${ }^{3}$ Legal Marxism was a Russian Marxist Movement based on specific interpretation of Marxist theory acknowledged for promoting its ideas in legal publications. 
believed in freedom of speech, founded new educational institutions (e.g., Nikolai A. Berdyaev).

As for logicians, the ability to reason made it possible to criticize the basic provisions of dialectical materialism. As a result, in 1921-1922, all departments of philosophy were closed because they hosted idealists; the most prominent representatives of philosophy and jurisprudence were expelled from the country. At the same time, teaching of logic and rhetoric ceased. The Revolution not only did not need historians, it also did not need people capable of independent reasoning.

However, after the closure of the departments of philosophy, the pre-revolutionary teachers of philosophy and logic were not left out of business. The higher education system reform took place: the old universities were preserved and new educational institutions appeared, such as the Institute of Philosophy, the Communist Academy, the Moscow Institute of Philosophy, Literature and Art, the Academy of Social Sciences, and they usually taught ancient literature, logic, rhetoric. The first proper legal educational institution was the All-Union Correspondence Law Institute (1931). In 1940, the so-called Military Institute of Foreign Languages (the name changed frequently) was founded. Its objective was to train personnel for military prosecutors' officers and military tribunals.

Teachers representing pre-revolutionary period were also involved in teaching (as bourgeois specialists in this area). Their further fate evolved in different ways, sometimes tragically. The fate of outstanding scholars Pavel A. Florensky, Gustav G. Shpet et al. was tragic. But most of the pre-revolutionary logicians survived terrible times and did not lose their qualifications. Since 1939, the "countdown" of a gradual return to the educational process began for logic. The idea of returning logic to education was inspired by the state authorities. For what purpose? The development of the independent thinking of workers and collective farmers could hardly have been the objective pursued by the governmental authorities. Most likely, the goal was to create proletarian logic as a variant of proletarian science as a whole. The priority of Soviet science as a proletarian science, as opposed to bourgeois science, was a favorite theme of the Soviet leadership. 
The process of creating proletarian Marxist-Leninist philosophy went through a number of stages, from a discussion between mechanists and dialecticians to writing a Short Course in the history of the AllUnion Communist Party of Bolshevics, from criticism of the History of Philosophy to a philosophical discussion led by Andrei A. Zhdanov in $1947 .{ }^{4}$ Finally, the turn came to logic, which was called formal logic and, apparently, was doomed in the same way as formal genetics. The role of proletarian logic was intended for dialectical logic. The procedure for the formation of proletarian logic went through a number of stages: from its return to the educational process to the foundation of the department of dialectical logic.

Logic as an academic discipline began to return to the educational process in 1946 after 25 years of almost complete oblivion. In prerevolutionary Russia, logic was taught in the senior grades of gymnasiums, in universities and theological schools according to a tradition established since the middle ages. In the 19th century, textbooks on logic written by Russian authors and scholars who contributed to the further creation of non-classical logic were published. Indeed, logic was not a leader in the national science, but it occupied quite a worthy place. The generation of logicians at the beginning of the 2oth century was represented by such scholars as Georgiy I. Chelpanov, Sergei I. Povarnin, Valentin F. Asmus, Pavel S. Popov, Aleksey A. Chudov, Semyon N. Vinogradov and others. It was they who, having started teaching logic at various educational institutions, survived the October Revolution; they saw the complete abolition of teaching logic as a "harmful science" in 1921, witnessed the departure of "philosophical steamers" 5 in 1922. For 25 years, they managed to teach logic and survived up to the Resolution of the Central Committee of the All-Union Communist Party (Bolsheviks) of 1946 on its renewal in the educational process (Georgiy I. Chelpanov died in 1936).

${ }^{4}$ Andrei A. Zhdanov, a revolutionary and Soviet politician and statesman, made a speech at a Conference of Soviet Philosophical Workers in 1947 where he accused philosophers of failing to develop Marxist-Lenin philosophy.

5 A collective name given to several steamers that in 1922 took out to West Europe a large group of most well-known Russia's scientists and scholars (almost 200 people) expelled out of Soviet Russia by the Soviet Regime. 
In the matter of reviving logic, a decisive role was played, oddly enough, by Iosif V. Stalin. Two common versions of that event have survived until now. Professor Avenir I. Uemov liked to voice the first version, according to which young philosophers Mark B. Mitin and Pavel F. Yudin are alleged to have come to Iosif Stalin and they asked when dialectical logics would be created. In response to that, Stalin suggested that they, first, should master the formal logics and demonstrated them Chelpanov's textbook published in 1946 that Stulin took out of his safe. The second version was voiced by Valentin A. Bazhanov (Bazhanov, 2007) who refers to the story told by Valentin F. Asmus. In early 1941, at night Valentin F. Asmus was summoned to the Kremlin to see Stalin. Stalin complained that his commissars did not know how to think, and they needed to be taught logic. However, the Great Patriotic War soon broke out, and the commissars fought without having mastered the science of correct thinking.

Meanwhile, the idea of the use of logic remained in the head of the former seminarian. In addition, Avenir I. Uemov (Uemov, 2000) remembered a story about Valentin F. Asmus being called to Vyacheslav M. Molotov, Chairman of the Council of People's Commissars of the USSR, who asked the scholar to give lectures on logic for members of the Soviet Government. These stories prove the existence of a certain interest in logic on the part of the country's party leadership. Perhaps, that interest was due to the needs of Soviet diplomacy that had not yet fully mastered the art of diplomatic discourse and was inferior in this field to Western diplomacy. Also, they might have seen in logic another powerful weapon of the working class. Having mastered it, one can bring the victory of Communism around the world closer by means of logics. The legend that Vladimir I. Ulyanov (Lenin) had only one "good" mark in his Education Certificate contributes to the understanding that the logics' destiny was predetermined, since the only good mark was given in logics. Thus, certain hopes for a miracle were associated with the restoration of logic.

As a result, on December 4, 1946, the Resolution of the Central Committee of the All-Union Communist Party of Bolsheviks (AUCP (b)) on Logic and Philosophy Teaching in Secondary Schools was adopted. The text of the Resolution reads: "The Central Committee 
of the AUCP (b) discussed the issue of teaching logic and psychology in secondary school and adopted a resolution on this issue. The Central Committee of the All-Union Communist Party of Bolsheviks admitted that it was absolutely abnormal that logic and psychology were not taught in secondary schools. The Central Committee of the AllUnion Communist Party (Bolsheviks) admitted that it was necessary to introduce, within four years, starting from the 1947/48 academic year, the teaching of psychology and logic in the graduating classes of secondary school. Logic and psychology should be taught by qualified teachers who have received special training in the field of psychology and logic."

The text of the Resolution was published, which was quite unusual, only in Uchitelskaya Gazeta [The Teachers' Newspaper]. An editorial in the "Uchitelskaya Gazeta" of December 14, 1946, reported the following: "Logic is of tremendous importance for disciplining our thinking. As a science about the laws of correct thinking, logic establishes those principles by following which we can avoid mistakes in our judgments and conclusions and come to correct, logically grounded evidence. The study of logic is excellent brain training, training our thinking to strict discipline. The practical use of logic is that it teaches people to make correct judgments, teaches to draw consistent inferences and seek rigorous evidence, which is so necessary for any mental activity. Logic fosters the economy of thinking, protecting from vain delusions, unnecessary, fruitless disputes that arise in the absence of justified, i.e., logical proof. The study of the logic of thinking is a necessary step for the study of dialectical logic." (Korsakov, 2016).

The introduction of logic into the educational process began earlier than the adoption of the Central Committee Resolution. The Department of Logic of the Faculty of Philosophy of Moscow State University was founded in 1943. In summer 1946, by the efforts of the department's faculty and specifically for the training of teachers of logic, special courses were initiated in Khimki town on the basis of the Institute of Culture. The Khimki Courses brought together future teachers of logic from all over the country. Yevgeniy K. Voishvillo, future professor of the Department of Logic, was among the participants of the courses. The courses lasted 6 weeks; lectures were given by Valentin F. Asmus, 
Pavel S. Popov, Aleksey A. Chudov and Semyon N. Vinogradov. They used, most likely, the preserved pre-revolutionary textbooks.

Frontal teaching of logic in universities and pedagogical institutes of the country began in the fall of 1947. The textbook by Georgiy I. Chelpanov, the textbook of logic for secondary schools by Smyon N. Vinogradov (first published for grammar schools in 1912) and the first Soviet textbook of logic by Valentin F. Asmus (published in March 1947) had a huge circulation of 100 thousand copies. As expected, there was no enough educational literature for everyone, the level of logic teachers was quite low, the academic discipline itself turned out to be difficult, both for students and teachers, and there were a lot of complaints on behalf of every participant of the process. The Ministry of Higher Education of the USSR checked the activities of the departments of logic of a number of universities, including the Department of Logic at Moscow State University.

On March 23, 1948, following the results of a ministerial audit held by the Department of Logic of Moscow State University (Order No 361 of the USSR Minister of Higher Education), Sergey V. Kaftanov, then the Minister of Higher Education of the USSR, condemned the department in general and personally Pavel S. Popov, Valentin F. Asmus and Semyon N. Vinogradov for formalism.

On June 21-26, 1948, the All-Union Conference on Logic was convened (Anisov and Malyukova, 2019) to discuss the Order No 361 of the USSR Minister of Higher Education and, more specifically, to discuss Asmus's textbook, The Conference took place in Moscow, in the Assembly Hall of Moscow State University and all the republics of the USSR and all university centers were represented there. At the meeting, a transcript was kept; it contained about 450 pages. The transcript was recently discovered among the papers of the now deceased Prof. Vyacheslav I. Kirillov, former head of the Department of Philosophy of Kutafin Moscow State Law University (MSAL).

The meeting was opened by the Deputy Minister of Higher Education of the USSR, Professor Vasiliy I. Svetlov. In his lengthy speech, he said the following:

"The All-Union Conference on Logic was convened after a year of practice in teaching logic. The introduction of a course in logic 
in universities is aimed not only at acquainting a wide range of students with this science, but also at training logic teachers for secondary schools. On this basis, about two years ago, the Ministry initiated courses for teachers of logic, and in 1947/1948 the expired academic year, special departments of logic and psychology were created in 16 universities and 15 pedagogical institutes.

As a result, a new group of logic teachers was created, albeit still unexperienced and having not enough knowledge, but already having a positive reputation. One of the evidence of this is the very fruitful acknowledgement of newly published books on logic, which was widely developed in the departments of logic and in the departments of dialectical materialism.

The teaching of logic itself should be structured so that it is alien to scholasticism, so that it is closely connected with the life of Soviet people, so that, like the teaching of all other disciplines, it should proceed from the decisions of the Central Committee of the All-Union Communist Party (bolshevics) on ideological issues. Unfortunately, some teachers of logic in higher educational institutions and authors of books and textbooks on the logic of the resolution of the Central Committee of the All-Union Communist Party of Bolsheviks (bolshevics) on ideological work and the resolution of the Central Committee of the AKP (bolshevics) on the introduction of teaching logic have not yet found a sufficiently complete reflection.

The teaching of logic and educational literature, which has recently appeared on logic, is often still built on materials from the distant past, in isolation from the achievements of Soviet science, in isolation from the practice of socialist construction. Meanwhile, logic, like any other science, cannot be apolitical, heeding good and evil with indifference.

However, some comrades working in the field of logic, and above all Comrade Asmus, they still do not understand this. After all, it is obvious that logic is a party, philosophical science, which must be expounded in the passionate language of a Bolshevik, and not in the dry, dry language of a pedant.

Unfortunately, the works of the classics of Marxism-Leninism are either not at all involved, or are involved to a very small extent, by some scientists and teachers of logic. On the other hand, as a serious gap, it 
should be noted that the development of questions of Marxist dialectical logic in our country is almost completely absent, or is carried out to a very weak extent."

The agenda of The All-Union Meeting of Teachers of Logic included the following issues:

1. Discussion of educational literature on logic.

2. The state of logic teaching in higher educational institutions.

3. Discussion of projects of syllabi and curricula for the course of logic.

In addition, the following theoretical reports were represented:

- The correlation between the scope and content of concepts (Prof. Bonifatii V. Kedrov).

- Logic and politics (Doctor of Philosophy Pyotr E. Vyshinsky).

- Against the idealistic interpretation of judgments (Doctor of Philosophy Pyotr V. Tavanets).

- The cognitive meaning of syllogism (Doctor of Philosophy Aleksey A. Chudov).

A large number of specialists spoke on the discussed issues and only 47 persons (Primakovskiy, 1955) (their names and opinions) were reflected in the Transcript of the Meeting. The most significant group of participants consisted of pre-revolutionary specialists. They all faced with various problems under the Soviet rule: Valentin F. Asmus (1894-1975), Pavel S. Popov (1892-1964) and Sergei N. Vinogradov in (1881-1954). They all were specialists in logics, authors of textbooks on logics, teachers of Khimki courses, but most importantly, they were charged with formalism under the Order of the Ministry. Indeed, the key figure of the Meeting was Aleksey A. Chudov (born in 1898 and employed by the Institute of Philosophy of the Academy of Sciences of the USSR) who possessed all the features of a specialist developed during the pre-revolutionary period. Since March 1, 1946, to March 1, 1948, he headed the Sector of Logics of the Institute of Philosophy. Unfortunately, we failed to determine the year of his death.

Before the Meeting, there were two textbooks on logics. One textbook was written by Mikhail S. Strogovich, the second textbook was written by Valentin F. Asmus. The fates of these two books was different. 
Mikhail S. Strogovich (1894-1984) is also one of the most outstanding logicians of that time. While writing his textbook, he taught logics at the Military University. He was not on the front line of fire. Moreover, he was a corresponding member of the Academy of Sciences and two textbooks on logic authored by him (1946 and 1948 editions) were even put as an example to Valentin F. Asmus. Among the pre-revolutionary logicians, one should name such specialists as Aleksey V. Savinov (1898-1956), Aleksandr S. Akhmanov (1893-1957), and Aleksandr O. Makovelsky (1884-1969).

Unlike most events that took place at that time, this Meeting did not end with anything. Valentin F. Asmus was never able to republish his textbook, and the collective textbook of 1956 did not become a significant event. The first generally valid textbook of the traditional type was "Logic" authored by Vyacheslav I. Kirillov and Anatoliy A. Starchenko that is still popular in our time. Many philologists still use books authored by Valentin F. Asmus. Incidentally, it was after this Meeting that Soviet logics for many years was drawn into a fruitless dispute over the relationship between dialectical and formal logic. The closure of the Department of Dialectical Logic at the Faculty of Philosophy of Moscow State University in 1968 that existed for only three years and did not create any notorious science became a symbol of its inglorious end. In addition, the leading figures of the Meeting managed to stop for a while the natural drift of traditional logic towards modern, mathematized logics. However, and this is the main thing, logics was still not acknowledged as a bourgeois science.

\section{Logical Science and Logical Education at Kutafin Moscow State Law University}

In the 50 and 60 s of the 2oth century, logics became a discipline the teaching of which was restored in universities and pedagogical educational institutions. Teaching logics in law schools ceased to be exclusive, i.e., without proper reasoning, in nature. Since 1961, Doctor of Philosophy (Logic) Vyacheslav I. Kirillov became the leading professor of logic of the All-Union Correspondence Law Institute, and then he headed the department. Due to his work and under his supervision, the standard 
of teaching logic for lawyers was formed. For this purpose, in 1963 Vyacheslav I. Kirillov and Anatoliy A. Starchenko (in the future, the long-term head of the Department of Logic of Moscow State University) wrote and published the textbook "Logic." The text of this textbook has become a classic, it has been republished many times, and there is also a less known version of this textbook written by Vyacheslav I. Kirillov on his own without the participation of Anatoliy A. Starchenko. In parallel with the textbook, a widely known problem book (book of problems) "Exercises in Logic" was published. The department is an attractive for logicians due to its determination to write and publish new textbooks on logic, rhetoric and the theory of argumentation (Afanasyeva, 2011; Demina, 2014; Demina and Przhilenskiy, 2017; Abramova and Nikulina, 2020a; Malyukova, 2018, 2021). The textbook "Logic" edited by Olga V. Malyukova is the most recent to be published (2021).

Over the years of its existence, the Department of Philosophy and Sociology has made a significant contribution to the development of the domestic science of logic. On July 15, 2013, the author of this paper discovered the Transcript of the All-Union Conference on Logic of 1948, the materials of which were used in writing the third section of this paper. Events unfolded as follows: on July 15, 2013, in the process of disassembling a bookcase in the office of the head of the department, the main contents of which involved numerous textbooks on logic once donated to Vyacheslav I. Kirillov by the authors and various editions of the textbook by Vyacheslav I. Kirillov, in the farthest corner of the bookcase on the very top shelf the author (Olga V. Malyukova) found a thick brown bound volume that looked like a doctoral dissertation. It was covered in dust, and the pages were covered with dried leaves of trees, as if someone had used this book to make a herbarium. Next to this volume was another rather valuable book - the well-known logical dictionary by Nikolay I. Kondakov. Naturally, I opened the first page of the most curious document I found. It turned out to be a typewritten text of the Transcript of the All-Union Conference on Logic held in 1948 , the volume consisting of 450 pages. It was the fourth, or even the fifth copy, typed on special and very thin paper, at least with two typewriters with different fonts. At first glance, the text was easy to read. However, what kind of the Meeting are we talking about? No one 
has ever referred to the proceedings of the Meeting. The Meeting has never been mentioned by anyone as if that Meeting never took place. The Meeting was not generally known among logicians. The found text belonged to Vyacheslav I. Kirillov who worked for many years at the Ministry of Higher Education, but he could hardly have participated in the Meeting due to his age.

Working with the text of the Transcript took a few years. In 2018, the Transcript was published in the monograph authored by Prof. Aleksandr M. Anisov and Prof. Olga V. Malyukova "The Formation of Domestic Logic: Discourses and Destinies." During the research work, the following conclusions were made:

1. The exact foundation date of the Sector of Logic of the Institute of Philosophy of the Academy of Sciences of the USSR and the name of the first head of the Sector were established. In accordance with the Decision of the Presidium of the USSR Academy of Sciences of December 23, 1947, a Sector of Logic was created at the Institute of Philosophy. On April 27, 1948, Aleksey A. Chudov, whose personality and identity still remain a mystery, was appointed as the head of the Sector from March.

2. It was determined that the opportunity to teach logic was assigned to teachers of the Russian language and literature, and not mathematics, as previously thought. In other words, logic was perceived as part of Russian/foreign literature, which corresponded to the ancient tradition.

3. The All-Union Conference on Logic was an important event in Russian history; the text of the Conference Transcript constitutes a precedent document of the era of the formation of Russian science and national education during the Soviet period; the preservation, discovery and publication of the text of this precedent document is the merit of the Department of Philosophy and Sociology of Kutafin Moscow State Law University (MSAL).

In 2023, we will celebrate 75 years since the Conference on Logic was held, which is a good reason for further research into the history of logic of the Soviet period. 


\section{Conclusion}

In conclusion, the following circumstances should be noted: by the 9oth Anniversary of Kutafin Moscow State Law University, the Department of Philosophy and Sociology has preserved the traditions of teaching logic laid down in Soviet times, and raised them to a new, modern level of teaching, i.e., using new textbooks and new digital techniques. Logic is taught in all institutes of Kutafin Moscow State Law University (MSAL) and it always encourages interest in studying logic among students. The disciplines taught by the department have expanded due to the widespread introduction of a new discipline of the logical cycle, namely, rhetoric. A detailed account of rhetoric is beyond the scope of this paper, but the inclusion of rhetoric in the educational process has raised the status of logic. And finally, scientific and educational activities of the Department of Philosophy and Sociology once again confirmed the importance of the concept of "legal logic," once formulated by Vyacheslav I. Kirillov. Legal logic has become essential in the field of methodology for the interpretation of legal norms. It is in this area that the logical methods of transforming normative legal judgments, deriving judgements by the methods of deduction, induction and analogy, proving by means of methods from the opposite and bringing to the absurd are applicable. Logic is a reliable toolkit for any humanist; it is especially significant for a lawyer in situations of rule of law, law enforcement and interpretation of legal norms.

\section{References}

1. Abramova, N.A. and Nikulina, I.A., (2020a). Rhetoric for Lawyers. Moscow: Prospekt (In Russ.).

2. Abramova, N.A. and Nikulina, I.A., (2020b). Rhetoric. A Study Guide for Specialitate. Moscow: Prospekt (In Russ.).

3. Afanasyeva, O.V., (2011). Logics. Moscow: Prospekt (In Russ.).

4. Anisov, A.M. and Malyukova, O.V., (2019). Formation of Domestic Logics: Discourses and Destinies: Monograph. Moscow: RG-Press (In Russ.).

5. Anisov, A.M., (2002). Modern Logics. Moscow: IFRAN Publ (In Russ.). 
6. Bazhanov, V.A., (2007). History of Logics in Russia and the USSR. Conceptual Context of University Philosophy. Moscow: Kanon+ (In Russ.).

7. Demina, L.A. and Przhilenskiy, V.I., (2017). Logics, Methodology, Argumentation in Scientific Research. Textbook for Graduate Students. Moscow: Prospect Publ (In Russ.).

8. Demina, L.A., (2014). Theory and Practice of Argumentation: Textbook. Moscow: Norma, INFRA-M (In Russ.).

9. Korsakov, S.N., (2016). From the History of the Revival of Logic in the USSR in 1941-46. Part II. Logical Investigations, 2, pp. 157-158 (In Russ.).

10. Livshits, V., (2009). Defense of Livshits: Lawyer's Stories. Moscow-St. Petersburg: AST, Astrel (In Russ.).

11. Malyukova, O.V., ed., (2018). Logics and Law: Monograph. Moscow: Prospekt (In Russ.).

12. Malyukova, O.V., ed., (2021). Logics: Textbook. Moscow: Prospekt (In Russ.).

13. Primakovskiy, A.P., (1955). Bibliography on Logic. Chronological Index of Works on Logics Issues Published in Russian in the USSR in the 18th-2oth Centuries. Moscow: Publishing house of the Academy of Sciences of the USSR (In Russ.).

14. Slinin, Ya.A. and Fedorov, B.I., (2001). Logics: Bio and Bibliographic Reference (Russia - USSR - Russia). St. Petersburg: Nauka Publ (In Russ.).

15. Uemov, A.I., (2000). I was Asmus's graduate student. "The Man" Online Journal. Available at: http://vivovoco.astronet.ru/VV/PAPERS/ BIO/ASMUS.HTM [Accessed 09.11.2021] (In Russ.).

\section{Information about the Author}

Olga V. Malyukova, Dr. Sci. (Philosophy), Associate Professor, Professor, Department of Philosophy and Social Studies, Kutafin Moscow State Law University (MSAL), Moscow, Russia

9 Sadovaya-Kudrinskaya ulitsa, Moscow 125993, Russia

o.maliukova@list.ru

ORCID: 0000-0002-9468-4874 